\title{
Depression as a Risk Factor for HIV Infection

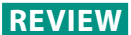

\begin{abstract}
Antônio de Luna Machado Neto', Nayara Luiza Pereira Rodrigues², Raimundo Tavares de Luna Neto ${ }^{2}$, Natália Bastos Ferreira² ${ }^{2}$, Alessandro Adamo Gonçalves Oliveira ${ }^{2}$ ,Woneska Rodrigues da Silva², Francisca Jeanny Sousa Rocha Viana ${ }^{2}$, Jucier Gonçalves Júnior ${ }^{3}$, Larissa Souza da $\mathrm{Cruz}^{3}$, Cláudio Couto Lóssio Neto ${ }^{3}$, Modesto Leite Rolim Neto ${ }^{1,2,3}$
\end{abstract}

\section{Abstract}

Major depression is the most common psychiatric diagnosis in Human Immunodeficiency Virus (HIV). However a few studies have focused on clinical depression as a risk factor for HIV infection. There are evidences to show that individuals with depressive symptoms can be predisposed to diseases such as HIV infection. Literature point out that the negative influence of depression as a risk factor for HIV can be explained because physical deterioration or depression can result in fatigue, physical impairment, and loss of motivation and self-confidence to engage in food and income generating activity. Other authors point out that this increased risk is thought to be due to high rates of substance use including injection drug use (IDU), risky sexual behavior, sexual victimization, and prostitution. It's consensus that are needed social support for HIV-infected patients that includes treatment for depression and substance abuse. Screening of depression should also be conducted regularly to provide a full psychiatric profile to decrease the risk of depression and improve quality of life in this population.

\section{Epidemiology}

Major depressive disorder is a chronic and disabling mental illness [1], worldwide the fourth leading illness causing functional disability [2, 3], associated with increased mortality and shortened lifespan [4, 5].

In 2011, it was estimated that more than 1.1 million people were living with HIVIAIDS and 50,000 people were newly diagnosed with HIV in the United States [6]. According to the World Health Organization and United Nations Program on HIVI AIDS (UNAIDS), 35.3 million people were HIV positive at the end of 2012, with 2.3 million new infections per year and 1.3 million deaths per year due to AIDS [7].
1 Faculty of Medicine, Estácio - FMJ, Juazeiro do Norte, Ceará, Brazil.

2 Pos-graduation Program in Health Sciences, Faculty of Medicine of ABC, Santo André, SP, Brazil.

3 Federal University of Cariri, Faculty of Medicine, Barbalha, Ceará, Brazil.

Contact information:

Jucier Gonçalves Júnior.

Tel: (055) (88)99176746

Address: 284, Divine Savior Street, Downtown, Barbalha, Ceará, Brazil, 63180000.

Æjuciergjunior@hotmail.com

Keywords

Depression; HIV; Risk Factor. 
Vol. 8 No. 100 doi: $10.3823 / 1699$
Major depression is the most common psychiatric diagnosis in Human Immunodeficiency Virus (HIV) with incidence rates estimated from 5\% and $42 \%$ up to $20 \%$ across the lifespan [8]. In a large nationally representative probability sample of persons living with HIV in the USA, 37\% screened positive for depression using a self-report $[9,10]$. In SubSaharian Africa the prevalence of around 8\% [11]. HIV-positive individuals are at a twofold to fivefold greater risk for depression than are HIV-negative individuals [12]. However, from a review of the current literature, it appeared that a few studies have focused on clinical depression as a risk factor for HIV infection. Most of the researches, in fact, have assessed depressive symptoms in patients who have already received HIV diagnosis [13].

\section{Depression as a risk factor for HIV}

There are evidence to show that individual with depressive symptoms can be predisposed to diseases such as HIV infection [14], diabetes, and even death from suicide $[15,16]$.

In multivariable models, individuals reporting schizophrenia (adjusted prevalence ratio $=1.68$, $95 \%$ confidence interval $=1.33-2.13)$, bipolar disease $(1.58,1.39-1.81)$, and depression and/or anxiety $(1.31,1.25-1.38)$ were more likely to be tested for HIV than persons without these diagnoses [17]. Wu et al [18] tried to identify vulnerable subgroups within the severely mentally ill population at elevated risk for HIV infection, administering the Colorado Symptom Index to 228 HIV positive and 281 HIV-negative subjects. The authors have found that a tool score $\geq 30$ was associated with a $47 \%$ increased risk for HIV infection.

Among 61,128 participants of the 2008 Behavioral Risk Factor Surveillance System survey, 65 years of age who responded to the question about HIV risk behaviors, 1,475 (3.4\% of weighted sample) reported they had one or more such behaviors in the preceding year. For male respondents, the prevalence of current major depression was 6.1\% (95\%
Cl: 3.9, 9.5) among 637 who reported having one or more HIV risk behaviors and 3.0\% (95\% Cl: 2.6, 3.4) among 23,142 who did not report having such behaviors ( $p=0.03$ ) [19]. Vujanovic et al [20] reports a series of hierarchical and logistic regression analyses was conducted and Depressive symptoms were significantly incrementally associated with worry about HIV infection.

\section{Depression as a promoter of risk behavior for HIV}

In the context of HIV, the negative influence of depression as a risk factor can be explained because physical deterioration or depression can result in fatigue, physical impairment, and loss of motivation and self-confidence to engage in food and income generating activity [21]. For other authors [22, 23] this increased risk is thought to be due to high rates of substance use including injection drug use (IDU), risky sexual behavior, sexual victimization, and prostitution.

On sexual risk behavior, there is evidence that rates of unprotected sex are higher among women than men - respectively, $56 \%$ and $43 \%$ of patients with severe mental illnesses in the last three months in the USA [24]. Gender-based inequalities, including cultural values (e.g., men should have many partners, women should be monogamous), socioeconomic context (e.g. unequal access to education, employment, increased violence, and restricted reproductive rights among women) which potentially place women at a disadvantage for negotiating safer sex or refusing unwanted sex, can partially explain differential rates of unprotected sex reported among men and women [25].

The findings of Tsai et al [26] suggest that forced sex is associated with adverse mental health outcomes among HIV-positive women in rural Uganda. The authors show in multivariable analyses that victimization was associated with greater depression symptom severity $(b=0.17 ; 95 \% \mathrm{Cl}=[0.02$, $0.33]$ ) and lower mental health-related quality of 
life $(b=-5.65 ; 95 \% C l=[-9.34,-1.96])$, as well as increased risks for probable depression (adjusted relative risk $[A R R]=1.58 ; 95 \% \mathrm{Cl}=[1.01,2.49)$ and heavy drinking (ARR $=3.99 ; 95 \% \mathrm{Cl}=[1.84$, 8.63]). For Nuttbrock et al [27], examined gender abuse and depressive symptoms as risk factors for HIV and other sexually transmitted infections (HIV/ STI) among male-to-female transgender persons (MTFs), the psychological vulnerability of younger MTFs to gender abuse apparently causes them to engage in high-risk sexual behavior and ultimately become HIV/STI infected.

Brandt et al [28] show that there was a significant interaction between depressive symptoms and emotion dysregulation in relation to HIV symptoms, HIV medication adherence due to medication side effects, avoidant coping, and distress tolerance. The form of the interaction indicated that patients live with HIV experiencing higher depressive symptoms and higher levels of emotion dysregulation reported the highest levels of HIV symptoms and lowest levels of distress tolerance. Additionally, results indicated that at lower levels of depressive symptoms, very high levels of emotion dysregulation predicted higher rates of medication nonadherence, whereas at higher levels of depressive symptoms, very high levels of emotion dysregulation predicted the lowest rates of medication nonadherence.

Higher counts of activated T cells were associated with fewer depression symptoms measured 12 months later in adjusted analysis in cohort [29]. These finding may be related to the fact that initiation of depression treatment is associated with better ART adherence in persons living with HIV/ AIDS [30]. Recent meta-analysis across 95 samples found depressive symptoms were significantly related to ART nonadherence [31]. Patients who dropped out of ART for $\geq 12$ months (Lost-to-Care, LTCs) had higher viral loads and depression, lower CD4+ counts, more alcohol, heroin, and injection drug use in the past 30 days [32]. On the other hand, persons with HIV and mental illness may be at risk for poor treatment adherence, development of treatmentresistant virus, and worse outcomes [33].

\section{Conclusion}

Therefore, the increased risk for HIV infections among persons with serve mental illness and the disproportionate burden of disease it represents for these people require more attention and more effective individualized treatments [23], since depression has a significant negative impact for HIVinfected patients, reducing their adherence to ART treatment, quality of life, treatment outcome, and functionality. In addition to hastening HIV disease progression and mortality, depression further may facilitate viral transmission contributing to a cycle of reinforcement between depression and HIV illness [13]. Thus, screening of depression should be conducted regularly to provide a full psychiatric profile to decrease the risk of depression and improve quality of life in this population [34]. Social support for HIV-infected patients that includes treatment for depression and substance abuse is likely to pay dividends in the form of lower nonAIDS mortality [35]. 


\section{References}

1. Murray CJ, Vos T, Lozano R, Naghavi M, Flaxman AD, Michaud $C$ et al. Disability-adjusted life years (DALYs) for 291 diseases and injuries in 21 regions, 1990-2010: a systematic analysis for the Global Burden of Disease Study 2010.Lancet. 2012; 380 (9859): 2197-2223.

2. Birnbaum HG, Kessler RC, Kelley D, Ben-Hamadi R, Joish VN, Greenberg PE. Employer burden of mild, moderate, and severe major depressive disorder: mental health services utilization and costs, and work performance. Depress Anxiety 2010; 27(1): 78-89.

3. Riihimäki K, Vuorilehto M, Isometsä E. A 5-year prospective study of predictors for functional and work disability among primary care patients with depressive disorders. Eur Psychiatry. 2015; 30: 51-57.

4. Whiteford HA, Degenhardt L, Rehm J, Baxter AJ, Ferrari AJ, Erskine $\mathrm{HE}$ et al. Global burden of disease attributable to mental and substance use disorders: findings from the Global Burden of Disease Study 2010. Lancet. 2013; 382 (9904): 1575-1586

5. Gálvez JF, Keser Z, Mwangi B, Ghouse AA, Fenoy AJ, Schulz PE et al. The medial forebrain bundle as a deep brain stimulation target for treatment resistant depression: A review of published data. Prog Neuropsychopharmacol Biol Psych. 2015; 58: 59-70.

6. CDC. Monitoring selected national HIV prevention and care objectives by using HIV surveillance data -United States and 6 U.S. dependent areas- 2011. HIV Surveillance Supplemental Report, 18(5) (2013) (Retrieved from http: //www.cdc.gov/hiv/ statistics/basics/ataglance.html).

7. Report of the global AIDS Epidemic 2013, Joint United Nations Program on HIVIAIDS,2013. [Access: 14th January, 2015]. Available: www.unaids.org/en/media/unaids/contentassets/ documents/epidemiology/2013/gr2013/unaids_global_ report_2013_en.pdf.

8. Mclntosh RC, Seay JS, Antoni MH, Schneiderman N. Cognitive vulnerability for depression in HIV. J Affect Disord. 2013; 150(3): 908-915.

9. Bing EG, Burnam MA, Longshore $D$, et al. Psychiatric disorders and drug use among human immunodeficiency virus-infected adults in the United States. Arch Gen Psychiatry. 2001; 58(8): 721-8.

10. Wagner GJ, Ghosh-Dastidar B, Dickens A, Nakasujja N, Okello E, Luryirika E et. al. Depression and its Relationship to Work Status and Income Among HIV Clients in Uganda. World J AIDS. 2012; 2(3): 126-134.

11. Abas M, Ali G-C, Nakimuli-Mpungu E, Chibanda D. Depression in people living with HIV in sub-Saharan Africa: time to act. Trop Med Int Health.2014; 19(12): 1392 -1396

12. Sin NL, DiMatteo NR. Depression Treatment Enhances Adherence to Antiretroviral Therapy: a Meta-Analysis. Ann. behav. med. 2014; 47: 259-269
13. Nanni MG, Caruso R, Mitchell AJ et al. Depression in HIV Infected Patients: a Review. Curr Psychiatry Rep.2015; 17: 530

14. Sherr L, Clucas C, Harding R, Sibley E, Catalan J. HIV and depression - a systematic review of interventions. Psychol Health Med.2011; 16: 493-527.

15. Pitpitan EV, Kalichman SC, Eaton LA, Sikkema KJ, Watt MH, Skinner D. Gender-based violence and HIV sexual risk behaviour: alcohol use and mental health problems as mediators among women in drinking venues, Cape Town. Soc. Sci. Med. 2012; 75 (8): 1417-1425.

16. Asante KO, Andon-Arthur J. Prevalence and determinants of depressive symptoms among university students in Ghana. J Affect Disord. 2015; 171: 161-166.

17. Yehia BR, Cui W, Thompson WW, Zack MM, McKnight-Eily L, DiNenno E et al. HIV Testing Among Adults with Mental Illness in the United States. AIDS Patient Care STDS.2014; 28(12): 628634.

18. Wu ES, Rothbard A, Blank MB. Using psychiatric symptomatology to assess risk for HIV infection in individuals with severe mental illness. Community Ment Health J. 2011; 47(6): 672-8.

19. Do A, Rosenberg E, Sullivan PS, Beer L, Strine T, Schulden JD, et al. Excess Burden of Depression among HIV-Infected Persons Receiving Medical Care in the United States: Data from the Medical Monitoring Project and the Behavioral Risk Factor Surveillance System. Plos One. 2014; 9(3): e92842.

20. Vujanovic A, Suchting R, Atkinson D,Green C, Schmitz J. Depressive symptoms and impulsivity among trauma-exposed, cocaine-dependent adults: Associations with HIV-relevant drug and sex risk behaviors. Drug AlcohoL Depen. 2015; 146: e13.

21. Wagner Gj, Goggin K, Remien RH et al. A Closer Look at Depression and Its Relationship to HIV Antiretroviral Adherence. Ann Behav Med. 2011; 42(3): 352-360.

22. Gottesman, Groome CS. HIV/AIDS risks as a consequence of schizophrenia. Schizophrenia Bull.1997; 23(4): 675-684.

23. Blank MB, Himelhoch S, Walkup J, Eisenberg MM. Treatment considerations for HIV-infected individuals with severe mental illness. Curr HIV/AIDS Rep. 2013; 10(4): 371-9.

24. Devieux JG, Malow R, Lerner BG, Dyer JG, Baptista L, Lucenko B, et al. Triple jeopardy for HIV: substance using severely mentally ill adults. J Prev Interv Community 2007; 33: 5-18.

25. Peixoto ERM, Barros FCR, Guimarães MDC. Factors associated with unprotected sexual practice among men and women with mental illnesses in Brazil. Cad. Saúde Pública. 2014; 30(7): 14751486.

26. Tsai AC, Wolfe WR, Kumbakumba E et al. Prospective Study of the Mental Health Consequences of Sexual Violence Among Women Living With HIV in Rural Uganda. J Interpers Violence. 2015; 0886260514567966 
27. Nuttbrock L, Bockting W, Rosenblum A et al. Gender Abuse, Depressive Symptoms, and HIV and Other Sexually Transmitted Infections Among Male-to-Female Transgender Persons: A Three-Year Prospective Study. Am J Public Health. 2013; 103(2): 300-307.

28. Brandt CP, Bakshaie J, Zvolensky MJ, Grover KW, Gonzalez A.The Examination of Emotion Dysregulation as a Moderator of Depression and HIV-Relevant Outcome Relations Among an HIV+Sample. Cogn Behav Ther.2015; 44(1): 9-20.

29. McGuire JL, Kempen JH, Localio R,Ellenberg JH, Douglas SD. Immune Markers Predictive of Neuropsychiatric Symptoms in HIV-Infected Youth. 2015; 22(1): 27-36.

30. Akincigil A, Wilson IB, Walkup JT, Siegel MJ, Huang C, Crystal S.Antidepressant treatment and adherence to antiretroviral medications among privately insured persons with HIVIAIDS. AIDS Behav.2011; 15(8): 1819-1828.

31. Gonzalez JS, Batchelder AW, Psaros C, Safren SA. Depression and HIVIAIDS treatment nonadherence: A review and metaanalysis.J Acquir Immune Defic Syndr. 2011; 58(2): 181-187.

32. Pecorato A, Mimiaga M, O'Cleirigh C et al.Depression, substance use, viral load, and CD4+ count among patients who continued or left antiretroviral therapy for HIV in St. Petersburg, Russian Federation. 2015; 27(1): 86-92.

33. Blank MB, Hanrahan NP, Fishbein M, Wu ES, Tennille JA, Ten Have TR et al. A randomized trial of a nursing intervention for HIV disease management among persons with serious mental illness. Psychiatr Serv. 2011; 62(11): 1318-24

34. Slot M, Sodemann M, Gabel C, Holmskov J, Laursen T, Rodkjaer L. Factors associated with risk of depression and relevant predictors of screening for depression in clinical practice: a crosssectional study among HIV-infected individuals in Denmark. HIV Med. 2015. [Acess in 15th January, 2015]. Available in: http: // www.ncbi.nlm.nih.gov/pubmed/25585857.

35. Wada N, Jacobson LP, Cohen $M$, French $A$, Phair J, Muñoz A. Cause specific life expectancies after 35 years of age for human immunodeficiency syndrome infected andhuman immunodeficiency syndrome negative individuals followed simultaneously in long-term cohort studies,1984-2008. Am J Epidemiol. 2013; 177 (2): 116-25.

\section{Comment on this article:}

\section{(f) $B$ in $8+\mathbf{S} \rho$}

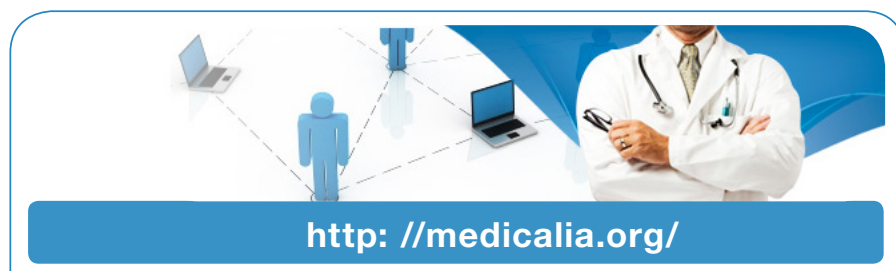

Where Doctors exchange clinical experiences, review their cases and share clinical knowledge. You can also access lots of medical publications for free. Join Now!

\section{Publish with iMedPub}

http: //www.imed.pub

International Archives of Medicine is an open access journal publishing articles encompassing all aspects of medical science and clinical practice. IAM is considered a megajournal with independent sections on all areas of medicine. IAM is a really international journal with authors and board members from all around the world. The journal is widely indexed and classified Q1 in category Medicine. 